\title{
Too young or too old: Evaluating cosmogenic exposure dating based on an analysis of compiled boulder exposure ages
}

\author{
Jakob Heyman ${ }^{\mathrm{a}, *}$, Arjen P. Stroeven ${ }^{\mathrm{a}}$, Jonathan M. Harbor ${ }^{\mathrm{b}}$, Marc W. Caffee ${ }^{\mathrm{c}}$ \\ ${ }^{a}$ Department of Physical Geography and Quaternary Geology, Stockholm University, 10691 Stockholm, Sweden \\ b Department of Earth and Atmospheric Sciences, Purdue University, West Lafayette, IN 47907-1397, USA \\ c Department of Physics, Purdue Rare Isotope Measurement Laboratory, Purdue University, West Lafayette, IN 47907-1397, USA
}

Editor: T.M. Harrison

\section{Keywords:}

cosmogenic nuclides

exposure age interpretation

prior exposure

incomplete exposure

glacial chronology

deglaciation

\begin{abstract}
A B S T R A C T
Cosmogenic exposure dating has greatly enhanced our ability to define glacial chronologies spanning several global cold periods, and glacial boulder exposure ages are now routinely used to constrain deglaciation ages. However, exposure dating involves assumptions about the geological history of the sample that are difficult to test and yet may have a profound effect on the inferred age. Two principal geological factors yield erroneous inferred ages: exposure prior to glaciation (yielding exposure ages that are too old) and incomplete exposure due to post-depositional shielding (yielding exposure ages that are too young). Here we show that incomplete exposure is more important than prior exposure, using datasets of glacial boulder ${ }^{10} \mathrm{Be}$ exposure ages from the Tibetan Plateau (1420 boulders), Northern Hemisphere palaeo-ice sheets (631 boulders), and present-day glaciers (208 boulders). No boulders from presentday glaciers and few boulders from the palaeo-ice sheets have exposure ages significantly older than independently known deglaciation ages, indicating that prior exposure is of limited significance. Further, while a simple post-depositional landform degradation model can predict the exposure age distribution of boulders from the Tibetan Plateau, a prior exposure model fails, indicating that incomplete exposure is important. The large global dataset demonstrates that, in the absence of other evidence, glacial boulder exposure ages should be viewed as minimum limiting deglaciation ages.
\end{abstract}

\section{Introduction}

The last few million years of Earth's history have included dramatic environmental changes associated with the growth and decay of glaciers and ice sheets (Ehlers and Gibbard, 2007). Beyond the global Last Glacial Maximum (LGM) at c. $20 \mathrm{ka}$, reconstructions of glacier and ice sheet chronologies rely heavily on cosmogenic nuclide measurements (e.g. Hein et al., 2009; Linge et al., 2006; Owen et al., 2006a). The application of cosmogenic exposure methodology has helped resolve a number of longstanding chronological and process debates in palaeoglaciology, including refuting the existence of an LGM Tibetan ice sheet (e.g. Owen et al., 2008) and demonstrating the ability of cold-based ice sheets to preserve even delicate pre-glacial landscape features (e.g. Briner et al., 2003, 2006a; Stroeven et al., 2002). However, the accuracy of cosmogenic exposure dating is limited by the basic physical principles of the method (Fabel and Harbor, 1999; Gosse and Phillips, 2001; Lal, 1991) and geological uncertainty (Briner et al., 2005a; Hallet and Putkonen, 1994; Putkonen and Swanson, 2003; Zech et al., 2005b).

\footnotetext{
* Corresponding author.

E-mail address: jakob.heyman@natgeo.su.se
}

Cosmogenic exposure dating is based on the principle that cosmogenic nuclides accumulate in the upper c. 3-5 m of Earth's surface as a result of bombardment by cosmic rays (Gosse and Phillips, 2001; Lal, 1991). Given nuclide-specific rates of cosmogenic nuclide accumulation, which are known to vary spatially and temporally (Balco et al., 2008; Gosse and Phillips, 2001; Owen et al., 2008), it is possible to convert measured concentrations into "apparent" exposure ages. The ages are considered apparent rather than definitive primarily because of the unknown geologic history of the sample, which includes the effects of prior exposure (inheritance) and incomplete exposure due to post-depositional shielding from cosmic rays (Applegate et al., 2010; Fabel and Harbor, 1999; Hallet and Putkonen, 1994; Putkonen and Swanson, 2003).

Samples used for exposure dating are typically taken from large boulders at the surface of glacial deposits (often moraines, i.e. ridges marking the maximum extent of glaciers and ice sheets). The ideal boulder has no inheritance and has resided at the surface since deglaciation (Fig. 1). Prior exposure to cosmic rays produces additional cosmogenic nuclides, an "inherited" component, yielding an apparent exposure age exceeding the deposition age. Incomplete exposure due to shielding, caused by burial and subsequent exhumation, results in reduced cosmogenic nuclide concentrations and yield apparent exposure ages underestimating the deposition age. Both prior exposure and incomplete exposure have been proposed as interpretation scenarios for glacial boulders, resulting 
a Ideal case

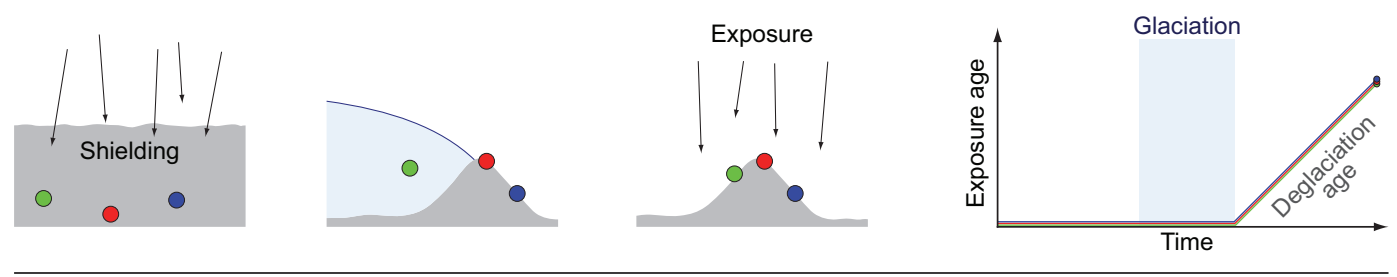

b Prior exposure
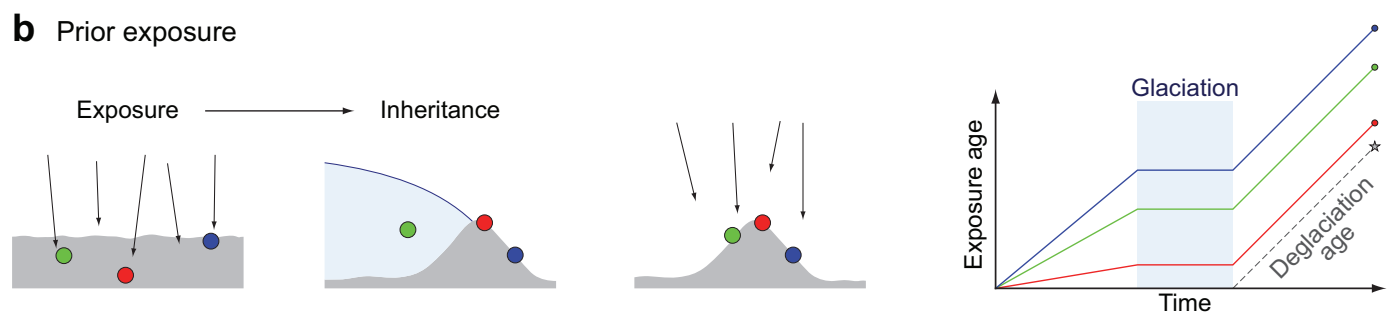

\section{Incomplete exposure}
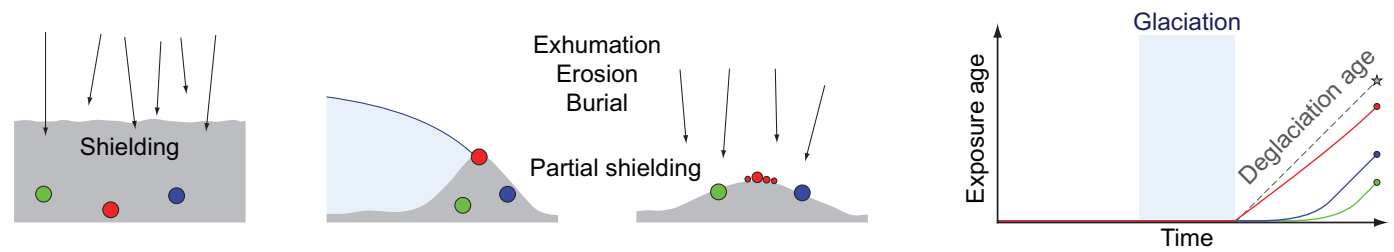

Fig. 1. Principles of prior exposure and incomplete exposure and resulting apparent exposure ages. (a) In the ideal case (for dating a deglaciation) the sample has been completely shielded from cosmic rays prior to glaciation and continuously exposed since deglaciation. (b) If a sample is exposed to cosmic rays prior to glaciation and experiences no postglacial shielding (prior exposure) the apparent exposure age will exceed the deglaciation age. (c) If a sample is completely shielded from cosmic rays prior to glaciation and partially shielded from cosmic rays following deglaciation (incomplete exposure) the apparent exposure age will be younger than the deglaciation age.

in the possibility of radically different exposure age interpretations (cf. Applegate et al., 2007; Barrows et al., 2007; Brown et al., 2005; Chevalier et al., 2005). Quantification of these geological effects on exposure ages has been based on numerical modelling (Applegate et al., 2010; Hallet and Putkonen, 1994; Putkonen and Swanson, 2003) and detailed field studies (Briner et al., 2005a; Davis et al., 1999). However, only limited attempts exist to reconcile models and measurements (cf. Briner et al., 2006a; Putkonen and O'Neal, 2006; Putkonen and Swanson, 2003).

We here present a compilation of published glacial boulder ${ }^{10} \mathrm{Be}$ exposure ages against which to test the prior exposure and incomplete exposure models. The comprehensive dataset of exposure ages comes from the Tibetan Plateau, areas formerly covered by the LGM Northern Hemisphere ice sheets, and present-day glaciers and recent moraines world-wide (Fig. 2; Table 1; Supplementary Dataset). The properties of these three glacial boulder datasets in terms of the inherent variety and quality of glacial histories and subglacial conditions (cold-based, warm-based) offer an excellent opportunity to test the importance of prior exposure and post-glacial shielding on apparent exposure ages.

\section{Methods}

\subsection{Data compilation}

Data for calculating ${ }^{10} \mathrm{Be}$ exposure ages were compiled from published literature (Table 1) and, where required, additional personal communication. Exposure ages were calculated using the CRONUS calculator (Balco et al., 2008; version 2.2; constants file version 2.2.1) applying a ${ }^{10} \mathrm{Be}$ half-life of $1.387 \mathrm{Ma}$ (Chmeleff et al., 2010; Korschinek et al., 2010) and reconciling measurements performed using various ${ }^{10} \mathrm{Be}$ standards (Nishiizumi et al., 2007) thus enabling the comparison of data from multiple sources. Sample density for all samples without measured densities was set to $2.7 \mathrm{~g} \mathrm{~cm}^{-3}$ (for CRONUS thickness shielding calculation). The erosion was set to zero for all samples and no scaling for post-glacial modification (such as burial by water or post-glacial uplift) was included. Thus, we calculate the apparent exposure ages assuming full and continuous post-glacial exposure in a geomorphologically inactive environment (Fig. 1a). Where multiple ${ }^{10} \mathrm{Be}$ measurements from a single boulder were performed (mostly replicate measurements) the uncertainty-weighted average of the exposure ages has been used as single boulder age. All exposure ages reported here are from the CRONUS Lm production rate scaling (Balco et al., 2008) based on the production rate scaling from Lal (1991) and Stone (2000) with palaeo-magnetic corrections following Nishiizumi et al. (1989). Changing the production rate scaling to another alters the individual exposure ages, in particular old exposure ages from the Tibetan Plateau (Supplementary Fig. S1), but not the overall exposure age pattern. The internal exposure age uncertainty, based on measurement uncertainty only (Balco et al., 2008), has an average of $4.5 \%$ with a maximum uncertainty of $36 \%$ for exposure ages $>10 \mathrm{ka}$. Because we focus on the large-scale exposure age pattern, the uncertainties associated with production rate scaling and ${ }^{10} \mathrm{Be}$ measurements do not challenge our analysis. See Supplementary Dataset for complete CRONUS input and output.

To quantify geological uncertainties (Fig. 3), each boulder from the palaeo-ice sheet dataset was given a deglaciation age based on deglaciation reconstructions (Dyke et al., 2003; Gyllencreutz et al., 2007a,b; Kleman et al., 2010). Because the deglaciation reconstructions are largely based on radiocarbon constraints they provide a means of independent testing of the apparent exposure ages (Supplementary Figs. S2, S3). Considering the uncertainties of the deglaciation reconstructions and the exposure age calculations, all boulders were given assumed deglaciation ages rounded to the nearest thousand years (Supplementary Figs. S2, S3; Supplementary Dataset). For the British Irish and Fennoscandian ice sheet areas (Fig. 2b,c) we have used the "probable" ice limit reconstruction from Gyllencreutz et al. (2007a,b). Extensive areas under the palaeo-ice sheets experienced cold-based non-erosive conditions (Kleman and 

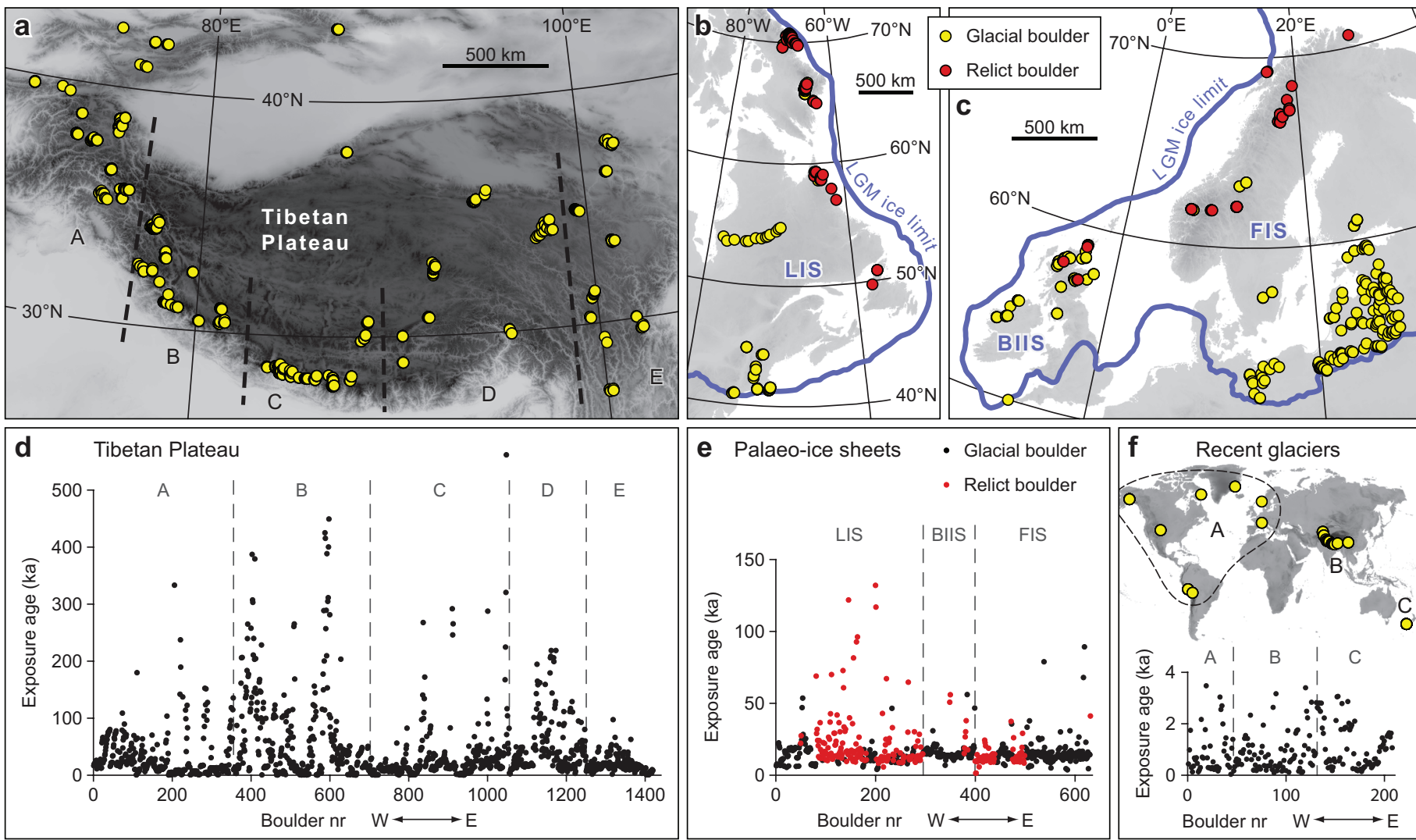

Fig. 2. Glacial boulder exposure age datasets. (a) Distribution of glacial boulder samples on the Tibetan Plateau. (b) Distribution of glacial boulder samples from the eastern Laurentide ice sheet (LIS). (c) Distribution of glacial boulder samples from the British Irish (BIIS) and Fennoscandian (FIS) ice sheets. The LGM ice limits are asynchronous (25-19 ka) maximum ice limits from deglaciation reconstructions (Gyllencreutz et al., 2007b; Kleman et al., 2010) largely based on radiocarbon dates. (d) Tibetan Plateau glacial boulder apparent exposure ages ordered from west to east. (e) Palaeo-ice sheet glacial boulder apparent exposure ages ordered from west to east. (f) Distribution of glacial boulders from recent glaciers and their apparent exposure ages ordered from west to east. For references and exposure age data, see Table 1 and Supplementary Dataset.

Hättestrand, 1999), and such relict areas (cf. Goodfellow, 2007) are potential source regions for glacial boulders with most pronounced inheritance. We have classified all boulders in the palaeo-ice sheet dataset as either boulders located on relict surfaces, preserved under non-erosive ice ("relict boulders"), or boulders located on glacially modified surfaces ("glacial boulders"; Supplementary Dataset). The classification is based primarily on published information but additional topographical analyses were performed for a few boulders.

Exposure ages from the Tibetan Plateau and the palaeo-ice sheet datasets were organized in groups (Supplementary Fig. S4) where each group represents a discrete glacial deposit with a certain deglaciation age (mostly single moraines), based on published information and boulder locations. The boulder exposure ages organized into groups of discrete glacial deposits allow assessment of the relative importance of prior exposure and incomplete exposure.

\subsection{Exposure age simulation}

To simulate the effect of prior exposure and incomplete exposure for the Tibetan Plateau boulder exposure age dataset, we developed two Monte Carlo exposure age models for multiples of all boulder groups (Supplementary Fig. S4). In the prior exposure model all boulders experience some degree of pre-depositional and complete post-depositional exposure to cosmic rays (Fig. 1b). In the incomplete exposure model all boulders are fully shielded prior to deposition and experience some degree of post-depositional shielding from cosmic rays (Fig. 1c). For detailed descriptions of the exposure age models, including their equations, see Supplementary Note: "Exposure age simulation" and Supplementary Figure S5.

In the prior exposure model each boulder is exposed to cosmic rays prior to glacial erosion and deposition. Each boulder group is assigned a random duration of prior exposure between zero and a maximum value, implying that all boulders from a certain group were derived from a landscape with the same exposure history. However, before erosion and entrainment by ice, each individual sample is assigned a random depth beneath the bedrock surface between zero and a maximum depth. The prior exposure for these boulders is therefore a function of the landscape exposure history and the depth beneath the surface from which they were mined. Calculation of the apparent exposure age acquired prior to deposition is based on the depth-dependent ${ }^{10} \mathrm{Be}$ production rate due to spallation (Lal, 1991) and muon interaction (Granger and Smith, 2000), assuming a bedrock density of $2.7 \mathrm{~g} \mathrm{~cm}^{-3}$. Each boulder group is assigned a random deglaciation (deposition) age which is added to the prior exposure component. The random deglaciation age varies between 0 and $250 \mathrm{ka}$, thus reflecting the range of measured boulder group minimum exposure ages (Fig. 4a). The duration of glaciation (period of shielding) between bedrock erosion and boulder deposition is assumed to be short-lived in comparison with the ${ }^{10} \mathrm{Be}$ half-life (1.387 $\mathrm{Ma})$ and ${ }^{10} \mathrm{Be}$ decay during ice burial is therefore not accounted for. No erosion occurs prior to glaciation or subsequent to deposition.

In the incomplete exposure model each boulder is fully shielded prior to deposition and therefore acquires an apparent exposure age of zero at deglaciation. Each boulder group is assigned a random deglaciation (deposition) age between 0 and $450 \mathrm{ka}$, thus reflecting the range of all but one measured boulder group maximum exposure ages (Fig. 4a). In this model, all boulders are shielded to some degree because they start at some random depth below the surface at the time of deposition. Hence, each boulder is assigned a random burial depth in till (density of $2.0 \mathrm{~g} \mathrm{~cm}^{-3}$ ) between zero and a maximum depth based on the deglaciation age and a time-dependent exhumation rate. All samples are exhumed following the same exhumation rate 
Table 1

Original publication and number of boulders for the glacial boulder exposure age datasets (see Supplementary Dataset).

\begin{tabular}{|c|c|c|c|c|c|}
\hline Publication & Boulders & Publication & Boulders & Publication & Boulders \\
\hline Tibetan Plateau & & Palaeo-ice sheet: LIS & & Recent glaciers & \\
\hline Abramowski (2004) & 28 & Balco and Schaefer (2006) & 14 & Abbühl et al. (2009) & 1 \\
\hline Abramowski et al. (2006) & 83 & Balco et al. (2002) & 22 & Barnard et al. (2004a) & 6 \\
\hline Aoki and Imamura (1999) & 2 & Balco et al. (2009) & 18 & Barnard et al. (2004b) & 4 \\
\hline Barnard et al. (2004a) & 15 & Briner (2003) & 3 & Barnard et al. (2006) & 6 \\
\hline Barnard et al. (2004b) & 15 & Briner et al. (2003) & 6 & Benson et al. (2007) & 6 \\
\hline Barnard et al. (2006) & 11 & Briner et al. (2005b) & 62 & Davis et al. (1999) & 3 \\
\hline Brown et al. (2002) & 4 & Briner et al. (2006b) & 10 & Dortch et al. (2010b) & 14 \\
\hline Chevalier et al. (in press) & 175 & Briner et al. (2007) & 9 & Finkel et al. (2003) & 4 \\
\hline Colgan et al. (2006) & 3 & Briner et al. (2008) & 2 & Heimsath and McGlynn (2008) & 10 \\
\hline Dortch et al. (2010a) & 18 & Carlson et al. (2007) & 13 & Kelly et al. (2008) & 4 \\
\hline Finkel et al. (2003) & 38 & Clark et al. (1995) & 4 & Licciardi et al. (2009) & 12 \\
\hline Gayer et al. (2006) & 4 & Clark et al. (2003) & 21 & Owen et al. (2001) & 1 \\
\hline Graf et al. (2008) & 17 & Davis et al. (2006) & 10 & Owen et al. (2005) & 12 \\
\hline Hedrick et al. (in press) & 47 & Gosse et al. (2006) & 5 & Owen et al. (2009) & 6 \\
\hline Heimsath and McGlynn (2008) & 10 & Kaplan et al. (2001) & 6 & Owen et al. (2010) & 9 \\
\hline Heyman et al. (2010) & 39 & Marquette et al. (2004) & 6 & Schaefer et al (2009) & 68 \\
\hline Kong et al. (2009a) & 15 & Marsella (1998) & 36 & Scherler et al. (2010) & 4 \\
\hline Kong et al. (2009b) & 11 & Marsella et al. (2000) & 37 & Seong et al. (2007) & 7 \\
\hline Koppes et al. (2008) & 26 & Staiger et al. (2005) & 11 & Seong et al. (2009) & 13 \\
\hline Laserre et al. (2002) & 11 & & $\Sigma 295$ & Shakesby et al. (2008) & 2 \\
\hline Mériaux et al. (2004) & 18 & Palaeo-ice sheet: BIIS & & Smith et al. (in press) & 4 \\
\hline Owen et al. (2001) & 24 & Ballantyne et al. (2007) & 3 & Winkler (2009) & 9 \\
\hline Owen et al. (2002) & 28 & Ballantyne et al. (2009) & 14 & Zech et al. (2009) & 3 \\
\hline Owen et al. (2003a) & 65 & Bradwell et al. (2008) & 10 & & $\Sigma 208$ \\
\hline Owen et al. (2003b) & 15 & Clark et al. (2009a) & 8 & & \\
\hline Owen et al. (2003c) & 18 & Clark et al. (2009b) & 16 & & \\
\hline Owen et al. (2005) & 67 & Everest and Kubik (2006) & 14 & & \\
\hline Owen et al. (2006a) & 55 & Everest et al. (2006) & 4 & & \\
\hline Owen et al. (2006b) & 46 & Golledge et al. (2007) & 3 & & \\
\hline Owen et al. (2009) & 59 & Lukas and Bradwell (2010) & 2 & & \\
\hline Owen et al. (2010) & 84 & McCarroll et al. (2010) & 5 & & \\
\hline Phillips et al. (2000) & 14 & Phillips et al. (2006) & 5 & & \\
\hline Pratt-Sitaula (2005) & 53 & Phillips et al. (2008) & 18 & & \\
\hline Schaefer et al. (2008) & 21 & Stone et al. (1998) & 2 & & \\
\hline Schäfer (2000) & 1 & & $\Sigma 104$ & & \\
\hline Schäfer et al. (2002) & 9 & Palaeo-ice sheet: FIS & & & \\
\hline Scherler et al. (2010) & 24 & Fabel et al. (2002) & 4 & & \\
\hline Seong et al. (2007) & 65 & Fabel et al. (2006) & 19 & & \\
\hline Seong et al. (2009) & 124 & Fjellanger et al. (2006) & 1 & & \\
\hline Strasky et al. (2009) & 5 & Goehring et al. (2008) & 37 & & \\
\hline Tschudi et al. (2003) & 2 & Harbor et al. (2006) & 2 & & \\
\hline Wang et al. (2003) & 1 & Heine et al. (2009) & 6 & & \\
\hline Wang et al. (2006) & 1 & Johnsen et al. (2009) & 6 & & \\
\hline Zech et al. (2005a) & 20 & Johnsen et al. (2010) & 6 & & \\
\hline Zech et al. (2009) & 17 & Matthews et al. (2008) & 3 & & \\
\hline \multirow[t]{7}{*}{ Zhou et al. (2007) } & 12 & Nesje et al. (2007) & 2 & & \\
\hline & $\Sigma 1420$ & Rinterknecht et al. (2004) & 9 & & \\
\hline & & Rinterknecht et al. (2005) & 37 & & \\
\hline & & Rinterknecht et al. (2006) & 91 & & \\
\hline & & Rinterknecht et al. (in press) & 5 & & \\
\hline & & Tschudi et al. (2000) & 4 & & \\
\hline & & & $\Sigma 232$ & & \\
\hline
\end{tabular}

decreasing exponentially with time, based on the assumption of diffusive moraine degradation (Applegate et al., 2010; Hallet and Putkonen, 1994; Putkonen and Swanson, 2003). Calculation of the apparent exposure age acquired during boulder exhumation is based on the depth-dependent ${ }^{10} \mathrm{Be}$ production rate due to spallation (Lal, 1991) and muon interaction (Granger and Smith, 2000). After a boulder is completely exhumed it is continuously and fully exposed to cosmic rays, implying an absence of boulder erosion.

To further quantify the relative importance of prior exposure and incomplete exposure for idealised exposure scenarios, the two models were coupled with the prior exposure component being subject to ${ }^{10} \mathrm{Be}$ decay after deposition (at random depth) following a random deglaciation age between 0 and $450 \mathrm{ka}$.

\section{Results and discussion}

The Tibetan Plateau area (Fig. 2a) has a large number of presentday glaciers and an extensive landform record of former glaciation. These glaciations appear to have been restricted to the highest mountain areas with alpine-style glaciers and ice-fields (Derbyshire et al., 1991; Lehmkuhl and Owen, 2005; Owen et al., 2008). The vast majority of the Tibetan Plateau boulders $(n=1420)$ are collected from moraine ridges formed by valley/outlet glaciers, and their apparent exposure ages range from $0.09 \pm 0.05 \mathrm{ka}$ to $561.7 \pm 54.8 \mathrm{ka}$ (Fig. 2d). The areas formerly glaciated by the Northern Hemisphere palaeo-ice sheets (Fig. 2b,c) as late as 8-25 ka ago (Dyke et al., 2003; Gyllencreutz et al., 2007a,b; Kleman et al., 2010) have been sampled for glacial boulders from a range of settings, including moraines, bedrock surfaces, and relict areas. The exposure ages of the relict 
boulders $(\mathrm{n}=228)$ range from $1.3 \pm 0.3 \mathrm{ka}$ to $131.9 \pm 11.9 \mathrm{ka}$ and the exposure ages of the glacial boulders $(n=403)$ range from $3.7 \pm 0.5$ ka to $89.2 \pm 9.5 \mathrm{ka}$ (Fig. 2e). The third dataset $(\mathrm{n}=208)$ is derived from 31 present-day glaciers and their late Holocene moraines $(<4$ ka) and has apparent exposure ages up to $3.5 \pm 0.4 \mathrm{ka}$ (Fig. 2f).

One consistent result is that none of the 208 boulders from recent glaciers have experienced substantial prior exposure (Fig. 2f). Using average Quaternary climate arguments for spatial and temporal glacier and ice sheet extents (Kleman and Stroeven, 1997; Kleman et al., 2008; Porter, 1989), boulders that were entrained by recent glaciers should only have been exposed for limited durations prior to entrainment because the recent geological history of currently glaciated areas has been dominated by glacial coverage. However, another expectation is that the highest likelihood of encountering glacial boulders with cosmogenic inheritance is in situations where long periods of exposure were punctuated by brief periods of ice burial. Such conditions existed for extensive marginal areas covered by the Northern Hemisphere palaeo-ice sheets, which were at their maximum extents for only limited durations (Kleman et al., 2008; Porter, 1989). Hence, glacial boulders from these areas should represent maximum likelihood samples for prior exposure.

a

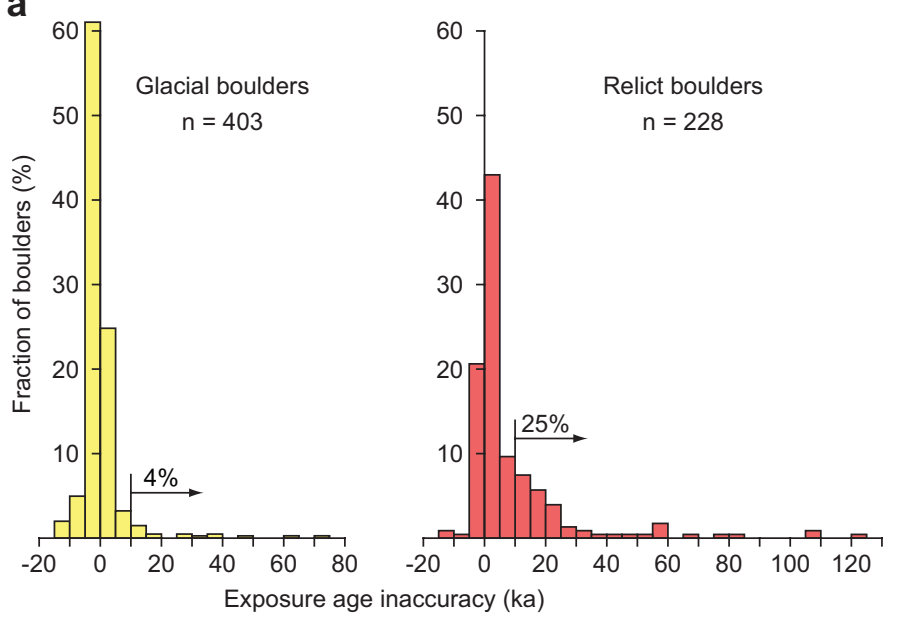

b

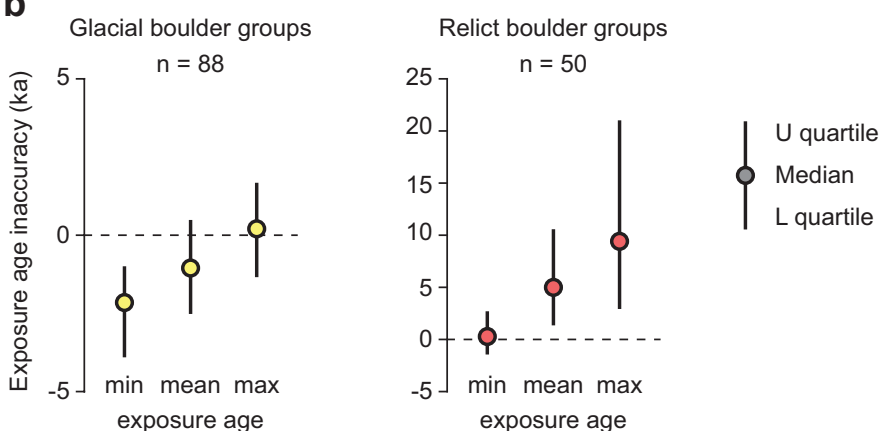

Fig. 3. Exposure age inaccuracy of the palaeo-ice sheet boulder exposure ages defined as ${ }^{10} \mathrm{Be}$ apparent exposure age minus corresponding reconstructed deglaciation age, largely based on radiocarbon constraints (Dyke et al., 2003; Gyllencreutz et al., 2007a,b; Kleman et al., 2010). (a) Exposure age inaccuracy frequency distribution of individual boulders divided into $5 \mathrm{ka}$ bins (horizontal axis). Positive numbers represent exposure ages older than reconstructed deglaciation ages and negative numbers represent exposure ages younger than reconstructed deglaciation ages. (b) Exposure age inaccuracy of multiple-boulder group ( $\geq 2$ boulders per group) minimum, mean, and maximum exposure ages shown as median and interquartile range. The relict boulder dataset has significantly higher exposure age inaccuracy with exposure ages older than deglaciation age. Patterns are similar for the Laurentide and European ice sheet areas (Supplementary Fig. S3). For exposure and deglaciation reconstruction ages, see Supplementary Dataset.
The palaeo-ice sheet dataset with ${ }^{10} \mathrm{Be}$ exposure ages and corresponding reconstructed deglaciation ages allow estimation of the amount and likelihood of prior exposure (Fig. 3a; Supplementary Dataset). Boulders from relict landscape surfaces, which have typically been dated to assess glacial erosion or ice sheet thickness (e.g. Briner et al., 2003; Fabel et al., 2002; Phillips et al., 2006), apparently deviate as much as $122 \mathrm{ka}$ from corresponding reconstructed deglaciation ages and $25 \%$ of them are more than $10 \mathrm{ka}$ older (Fig. 3a). For relict boulders organized into groups, the group minimum exposure age is typically closest to the corresponding deglaciation age (Fig. 3b). Boulders in glacially modified areas are up to $70 \mathrm{ka}$ older than corresponding deglaciation ages but only $4 \%$ of them are more than $10 \mathrm{ka}$ older (Fig. 3a). An overwhelming 86\% of the boulders in glacially modified areas have apparent exposure ages that fall within $5 \mathrm{ka}$ of the corresponding deglaciation ages. For glacial boulders organized into groups, the group maximum exposure age is typically closest to the corresponding deglaciation age (Fig. 3b). The low percentages of glacial boulders with apparent exposure ages more than $10 \mathrm{ka}$ older than independent deglaciation ages, especially in glacially modified areas, indicate that exposure prior to glaciation is of limited importance, even for these areas with the most favourable conditions for prior exposure.

The Tibetan Plateau boulders organized into groups (Fig. 4a,b; Supplementary Fig. S6) have minimum ages ranging from 0 ka to $246 \mathrm{ka}$, and maximum ages ranging from $0 \mathrm{ka}$ to $562 \mathrm{ka}$. The oldest maximum exposure age for each group increases rapidly with group minimum exposure age from $51 \mathrm{ka}$ to $287 \mathrm{ka}$ for group minimum exposure ages between $1 \mathrm{ka}$ and $18 \mathrm{ka}$, and the youngest minimum exposure age for each group increases moderately with group maximum exposure age from $1 \mathrm{ka}$ to $106 \mathrm{ka}$ for group maximum exposure ages between $51 \mathrm{ka}$ and 449 ka (Fig. 4a; Supplementary Dataset). Exposure age spreads within the boulder groups, represented by group exposure age standard deviation, range from 0 ka to $174 \mathrm{ka}$ and increase with both group maximum and minimum exposure ages (Fig. 4b; Supplementary Dataset). These measured boulder group exposure age properties were used to evaluate the exposure age Monte Carlo simulations against.

For the prior exposure model a number of simulations were performed with varying maximum duration of prior exposure and maximum prior sample depth. Figure $4 \mathrm{c}$ shows the exposure age pattern adopting a maximum duration of prior exposure of $150 \mathrm{ka}$ and a maximum prior sample depth of $5 \mathrm{~m}$. The $150 \mathrm{ka}$ maximum prior exposure duration is based on exposure ages of bedrock surface samples collected from unglaciated areas on the Tibetan Plateau (Kong et al., 2007; Lal et al., 2003; Supplementary Fig. S7; Supplementary Dataset). The exposure age pattern resulting from these boundary conditions bears a poor resemblance to the measured data (Fig. 4c,d). The exposure age spread within the boulder groups is constant over the range of group minimum exposure ages resulting in too large an age spread for the youngest group minimum exposure ages and too small an age spread for the oldest group minimum exposure ages. The exposure age spread increases with group maximum exposure age but this increase is still significantly smaller than shown by the measured group maximum exposure ages. The poor performance of the model could potentially be an effect of the constant maximum prior exposure duration. Repeated glacial erosion over time with successively smaller glaciers (cf. Owen et al., 2010), removing the uppermost bedrock layers, may have resulted in decreased maximum prior exposure for younger glaciation boulders (cf. present-day glaciers dataset). However, with the duration of maximum prior exposure increasing linearly from 0 to $400 \mathrm{ka}$ with deglaciation age, and a maximum prior sample depth of only $2 \mathrm{~m}$ to elicit high inheritance, the simulated group exposure age spread is still smaller than in the measured dataset for both group minimum and maximum exposure ages (Supplementary Fig. S8). In summary, adopting reasonable assumptions regarding prior exposure duration and sample depth does not allow the prior exposure model to 


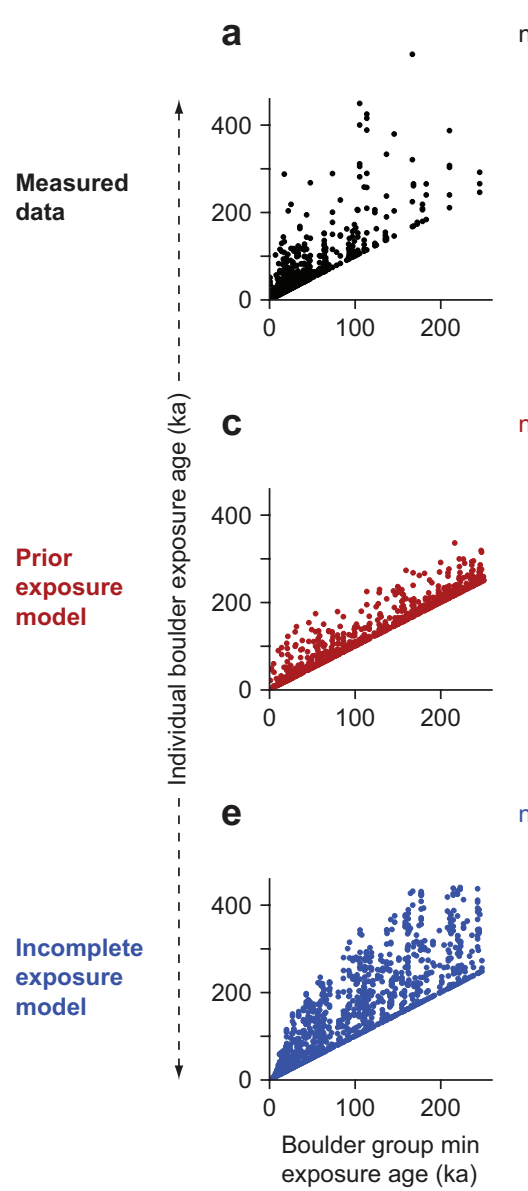

$n=1361$ boulders

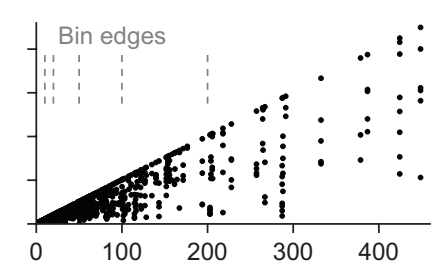

$\mathrm{n}=1361$ boulders

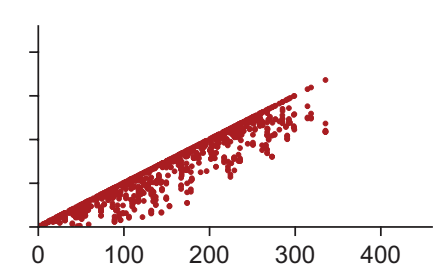

$n=1361$ boulders

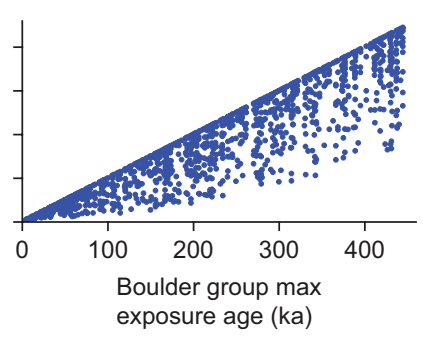

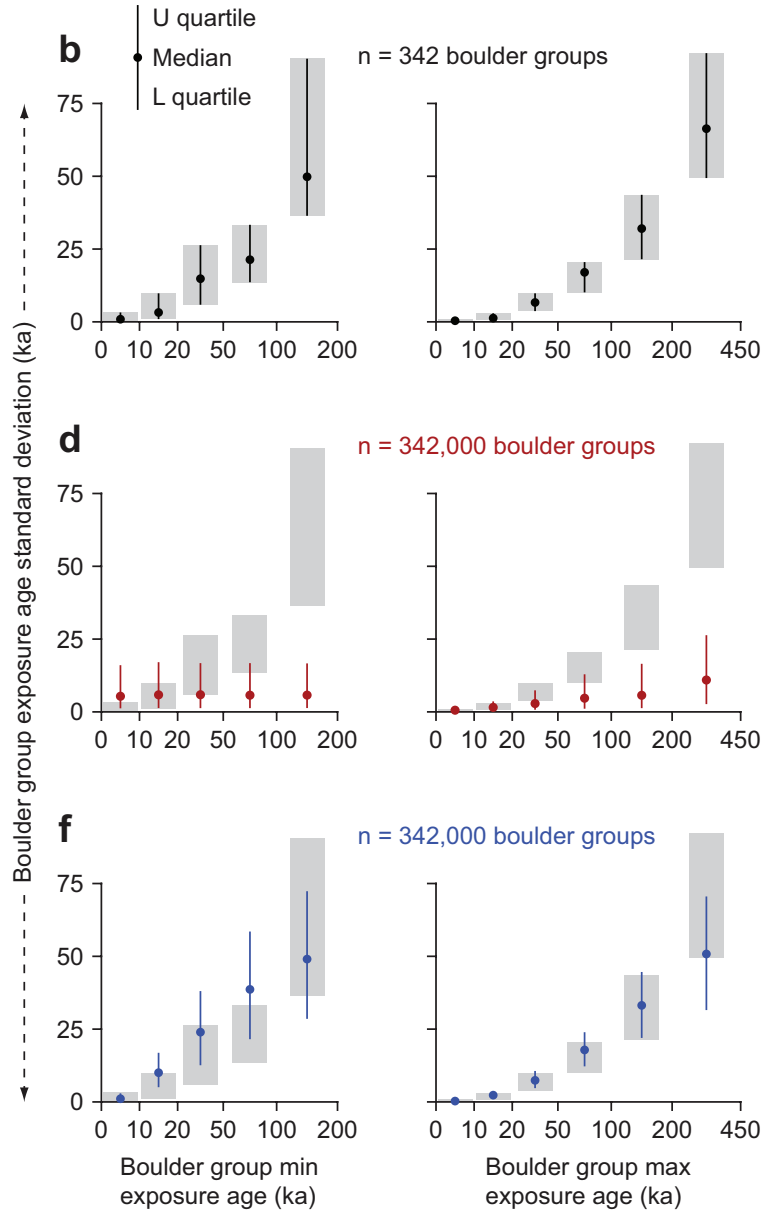

Fig. 4. Measured and simulated Tibetan Plateau individual exposure ages (a, c, and e) and exposure age spreads (b, d, and f) from multiple-boulder groups ( $\geq 2$ boulders per group) against boulder group minimum and maximum exposure ages. (a) Measured individual boulder exposure ages. For details, see Supplementary Figure S6 or Supplementary Dataset. (b) Measured boulder group exposure age spread shown as group standard deviation (median and interquartile range) for bins with bin edges at 10, 20, 50, 100, and 200 ka. (c) Simulated individual exposure ages for the prior exposure model adopting a maximum duration of prior exposure of $150 \mathrm{ka}$ and a maximum prior sample depth of $5 \mathrm{~m}$. (d) Simulated boulder group exposure age spread for the prior exposure model. The grey areas show the interquartile range of the measured data for comparison. (e) Simulated individual exposure ages for the incomplete exposure model. (f) Simulated boulder group exposure age spread for the incomplete exposure model. The grey areas show the interquartile range of the measured data for comparison. The incomplete exposure model predicts the measured exposure age pattern significantly better than the prior exposure model.

successfully predict the measured exposure age pattern.

In the incomplete exposure model (Fig. 4e,f) an exponential exhumation rate is adopted that starts at $11 \mathrm{~cm} \mathrm{ka}^{-1}$ at deglaciation and which yields $10.9 \mathrm{~m}$ of exhumation over $450 \mathrm{ka}$ (Supplementary Fig. S5). This time-dependent exhumation rate reflects the degradation of a small and slowly degrading moraine employing the diffusion model of Applegate et al. (2010). The incomplete exposure model reveals increasing group exposure age spreads for both group minimum and maximum exposure ages of similar magnitude as in the measured dataset (Fig. 4e, f). For group minimum exposure ages between 10 and $100 \mathrm{ka}$ the simulated group exposure age spread is slightly higher than in the measured data whereas for the oldest group maximum exposure ages the simulated age spread is slightly lower than in the measured data. However, considering the simple structure of the model, including the same time-dependent exhumation rate for each boulder, the output captures the main characteristics of the measured dataset remarkably well.

The predictive power of the incomplete exposure model is significantly stronger than the predictive power of the prior exposure model (Fig. 4). This corroborates an interpretation of the Tibetan Plateau boulder exposure ages as altered by incomplete exposure more than by prior exposure. To further analyse the relative importance of the two competing geological factors, we have quantified the exposure age inaccuracy (relative to deglaciation age) for two idealised cases with either high inheritance or low inheritance using the coupled model (Fig. 5). In both cases the boulders are shielded from cosmic rays due to post-depositional exhumation following the time-dependent exhumation rate of the incomplete exposure model (Fig. 4e, f; Supplementary Fig. S5). The high inheritance model has a maximum prior exposure duration of $150 \mathrm{ka}$ and a maximum prior sample depth of $5 \mathrm{~m}$. The low inheritance model has a maximum prior exposure duration of $50 \mathrm{ka}$ and a maximum prior sample depth of $10 \mathrm{~m}$. Figure 5 shows the inaccuracies of simulated boulder group minimum, mean, and maximum exposure ages against deglaciation age. Comparing the model output for the deglaciation age range of 10-20 ka with the measured palaeo-ice sheet boulder group data (Fig. 3b), the relict boulder group exposure ages are best predicted by the high inheritance model while the glacial boulder group exposure ages are best predicted by the low inheritance model. The model results illustrate the stronger impact of incomplete exposure over prior exposure and the incomplete exposure dependence on deglaciation age. In the high inheritance model boulder group maximum exposure ages are more accurate than mean or minimum exposure ages for boulder groups older than $50 \mathrm{ka}$. In the low inheritance model boulder group maximum ages are more accurate than mean or minimum exposure ages for boulder groups older than $10 \mathrm{ka}$. For a boulder group with a deglaciation age of 50-60 ka, the typical mean exposure age will be $10 \mathrm{ka}$ too young using the high inheritance model and $16 \mathrm{ka}$ too young using the low inheritance model. These results illustrate the potential pitfall in using mean 

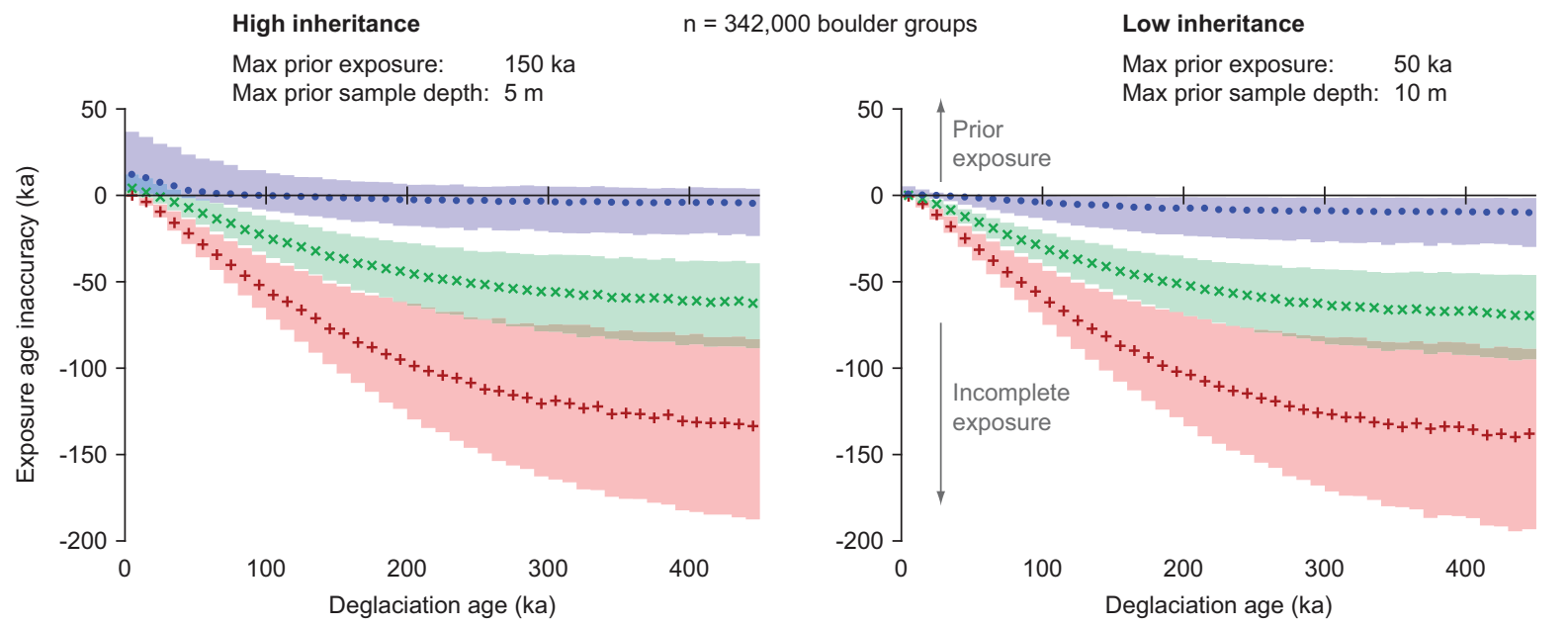

- max exp age
$\times$ mean exp age
+ min exp age

U quartile

Median

L quartile

Fig. 5. Simulated exposure age inaccuracy for coupled prior and incomplete exposure models. In the high inheritance model the prior exposure component is given by a maximum duration of prior exposure of $150 \mathrm{ka}$ and a maximum prior sample depth of $5 \mathrm{~m}$ (cf. Fig. 4c,d). In the low inheritance model the prior exposure component is given by a maximum duration of prior exposure of $50 \mathrm{ka}$ and a maximum prior sample depth of $10 \mathrm{~m}$. For both the high and the low inheritance models the post-depositional shielding is given by the time-dependent exponential exhumation rate employed in the incomplete exposure model (cf. Fig. 4e,f; Supplementary Fig. S5). The exposure age inaccuracy (vertical axis) of the boulder group minimum, mean, and maximum exposure age (median and interquartile range) is shown against deglaciation age (horizontal axis) divided into $10 \mathrm{ka}$ bins. Incomplete exposure is shown to be more important than prior exposure, with the boulder group maximum exposure age typically yielding the best accuracy (for all deglaciation ages $>50 \mathrm{ka}$ in the high inheritance model and $>10 \mathrm{ka}$ in the low inheritance model).

exposure ages to infer deglaciation age for boulder groups with wide exposure age spread. Unless prior exposure and incomplete exposure have altered the cosmogenic nuclide concentrations of a boulder group by equal amounts, which is arguably unlikely for boulder groups with wide exposure age spreads considering the diverse pre- and post-depositional geological processes, the mean exposure age will deviate from the deglaciation age.

The results of our analysis of three separate boulder exposure age datasets is distinct: incomplete exposure is generally more important than prior exposure implying that boulder exposure ages typically underestimate the deposition/deglaciation age. However, prior exposure appears to dominate in areas that have been preserved under non-erosive ice (cf. Briner et al., 2006a; Fabel et al., 2002) as illustrated by the palaeo-ice sheet relict boulder dataset (Fig. 3). Further, cosmogenic inheritance from prior exposure occasionally occur in boulders from glacially modified landscapes (cf. Balco et al., 2002; Owen et al., 2009; Rinterknecht et al. 2006) complicating exposure age interpretations. For cosmogenic dating applications our boulder exposure age compilation provides a reference dataset against which to evaluate expected exposure age accuracy.

\section{Conclusions}

The superior performance of the incomplete exposure model over the prior exposure model (Fig. 4) to explain the apparent exposure age structure of a comprehensive cosmogenic nuclide dataset from the Tibetan Plateau, combined with an absence of cosmogenic inheritance $>3.5 \mathrm{ka}$ in boulders from recent glaciers (Fig. 2f) and a low-frequency of inheritance in boulders from glacially-modified palaeo-ice sheet locations (Fig. 3) lends strong support to the argument that post-depositional shielding is the most important geological process leading to scatter in cosmogenic exposure ages for glacial boulder groups older than a few thousand years. Our analysis of global ${ }^{10} \mathrm{Be}$ exposure ages indicates that apparent cosmogenic nuclide exposure ages for a majority of all glacial boulders represent minimum ages for deposition/deglaciation. For boulder groups with wide exposure age spreads, the maximum apparent exposure age should, in the absence of independent indications of prior exposure, normally be viewed as a minimum deglaciation age.

\section{Acknowledgements}

We thank everyone who has shared unpublished data for the exposure age compilation, Richard Gyllencreutz and Johan Kleman for providing deglaciation reconstructions, and Patrick Applegate and Lewis Owen for key improvements. We thank Greg Balco and an anonymous reviewer for constructive and helpful reviews. The exposure age simulations were carried out using Octave version 3.2.4 (http://www.octave.org/) with m-file codes that can also be executed in MATLAB. These m-files are available as supplementary files.

\section{References}

Abbühl, L.M., Akçar, N., Strasky, S., Graf, A.A., Ivy-Ochs, S., Schlüchter, C., 2009. A zeroexposure time test on an erratic boulder: evaluating the problem of pre-exposure in surface exposure dating. Eiszeitalter und Gegenwart, Quat. Sci. J. 58, 1-11.

Abramowski, U., 2004. The use of ${ }^{10} \mathrm{Be}$ surface exposure dating of erratic boulders in the reconstruction of the late Pleistocene glaciation history of mountainous regions, with examples from Nepal and Central Asia. PhD Thesis, University of Bayreuth.

Abramowski, U., Bergau, A., Seebach, D., Zech, R., Glaser, B., Sosin, P., Kubik, P.W., Zech, W., 2006. Pleistocene glaciations of central Asia: results from ${ }^{10} \mathrm{Be}$ surface exposure ages of erratic boulders from the Pamir (Tajikistan), and the Alay-Turkestan range (Kyrgyzstan). Quat. Sci. Rev. 25, 1080-1096.

Aoki, T., Imamura, M., 1999. Reconstructing the glacial chronology based on the ${ }^{10} \mathrm{Be}$ exposure age - the case study of the Khumbu Glacier, eastern Nepal Himalayas. Bull. Nat. Museum Japan. Hist. 81, 517-525.

Applegate, P.J., Lowell, T.V., Alley, R.B., 2007. Comment on "Absence of cooling in New Zealand and the adjacent ocean during the Younger Dryas chronozone". Science 320, 746.

Applegate, P.J., Urban, N.M., Laabs, B.J.C., Keller, K., Alley, R.B., 2010. Modeling the statistical distributions of cosmogenic exposure dates from moraines. Geosci. Model Dev. 3, 293-307.

Balco, G., Schaefer, J.M., 2006. Cosmogenic-nuclide and varve chronologies for the deglaciation of southern New England. Quat. Geochron. 1, 15-28.

Balco, G., Stone, J.O.H., Porter, S.C., Caffee, M.W., 2002. Cosmogenic-nuclide ages for New England coastal moraines, Martha's Vineyard and Cape Cod, Massachusetts, USA. Quat. Sci. Rev. 21, 2127-2135. 
Balco, G., Stone, J.O., Lifton, N.A., Dunai, T.J., 2008. A complete and easily accessible means of calculating surface exposure ages or erosion rates from ${ }^{10} \mathrm{Be}$ and ${ }^{26} \mathrm{Al}$ measurements. Quat. Geochron. 3, 174-195.

Balco, G., Briner, J., Finkel, R.C., Rayburn, J.A., Ridge, J.C., Schaefer, J.M., 2009. Regional beryllium-10 production rate calibration for late-glacial northeastern North America. Quat. Geochron. 4, 93-107.

Ballantyne, C.K., McCarroll, D., Stone, J.O., 2007. The Donegal ice dome, northwest Ireland: dimensions and chronology. J. Quat. Sci. 22, 773-783.

Ballantyne, C.K., Schnabel, C., Xu, S., 2009. Readvance of the last British-Irish ice sheet during Greenland interstade 1 (GI-1): the Wester Ross readvance, NW Scotland. Quat. Sci. Rev. 28, 783-789.

Barnard, P.L., Owen, L.A., Finkel, R.C., 2004a. Style and timing of glacial and paraglacial sedimentation in a monsoon-influenced high Himalayan environment, the upper Bhagirathi Valley, Garhwal Himalaya. Sed. Geol. 165, 199-221.

Barnard, P.L., Owen, L.A., Sharma, M.C., Finkel, R.C., 2004b. Late Quaternary (Holocene) landscape evolution of a monsoon-influenced high Himalayan valley, Gori Ganga, Nanda Devi, NE Garhwal. Geomorphology 61, 91-110.

Barnard, P.L., Owen, L.A., Finkel, R.C., Asahi, K., 2006. Landscape response to deglaciation in a high relief, monsoon-influenced alpine environment, Langtang Himal, Nepal. Quat. Sci. Rev. 25, 2162-2176.

Barrows, T.T., Lehman, S.J., Fifield, L.K., De Deckker, P., 2007. Absence of cooling in New Zealand and the adjacent ocean during the Younger Dryas chronozone. Science 318, 86-89.

Benson, L., Madole, R., Kubik, P., McDonald, R., 2007. Surface-exposure ages of Front Range moraines that may have formed during the Younger Dryas, $8.2 \mathrm{cal} \mathrm{ka}$, and little ice age events. Quat. Sci. Rev. 26, 1638-1649.

Bradwell, T., Fabel, D., Stoker, M., Mathers, H., Mchargue, L., Howe, J., 2008. Ice caps existed throughout the lateglacial interstadial in northern Scotland. J. Quat. Sci. 23, 401-407.

Briner, J.P., 2003. The last glaciation of the Clyde region, northeastern Baffin Island, arctic Canada: cosmogenic isotope constraints on Laurentide ice sheet dynamics and chronology. PhD thesis, University of Colorado, Boulder.

Briner, J.P., Miller, G.H., Davis, P.T., Bierman, P.R., Caffee, M., 2003. Last glacial maximum ice sheet dynamics in arctic Canada inferred from young erratics perched on ancient tors. Quat. Sci. Rev. 22, 437-444.

Briner, J.P., Kaufman, D.S., Manley, W.F., Finkel, R.C., Caffee, M.W., 2005a. Cosmogenic exposure dating of late Pleistocene moraine stabilization in Alaska. Geol. Soc. Am. Bull. 117, 1108-1120.

Briner, J.P., Miller, G.H., Davis, P.T., Finkel, R.C., 2005b. Cosmogenic exposure dating in arctic glacial landscapes: implications for the glacial history of northeastern Baffin Island, arctic Canada. Can. J. Earth Sci. 42, 67-84.

Briner, J.P., Gosse, J.C., Bierman, P.R., 2006a. Applications of cosmogenic nuclides to Laurentide Ice Sheet history and dynamics. Geol. Soc. Am. Spec. Paper 415, $29-41$.

Briner, J.P., Miller, G.H., Davis, P.T., Finkel, R.C., 2006b. Cosmogenic radionuclides from fiord landscapes support differential erosion by overriding ice sheets. Geol. Soc. Am. Bull. 118, 406-420.

Briner, J.P., Overeem, I., Miller, G., Finkel, R., 2007. The deglaciation of Clyde Inlet, northeastern Baffin Island, arctic Canada. J. Quat. Sci. 22, 223-232.

Briner, J.P., Miller, G.H., Finkel, R., Hess, D.P., 2008. Glacial erosion at the fjord onset zone and implications for the organization of ice flow on Baffin Island, arctic Canada. Geomorphology 97, 126-134.

Brown, E.T., Bendick, R., Bourlès, D.L., Gaur, V., Molnar, P., Raisbeck, G.M., Yiou, F., 2002. Slip rates of the Karakorum fault, Ladakh, India, determined using cosmic ray exposure dating of debris flows and moraines. J. Geophys. Res. 107, B9 2192.

Brown, E.T., Molnar, P., Bourlès D.L., 2005. Comment on "Slip-rate measurements on the Karakorum Fault may imply secular variations in Fault motion”. Science 309, 1326.

Carlson, A.E., Clark, P.U., Raisbeck, G.M., Brook, E.J., 2007. Rapid Holocene deglaciation of the Labrador sector of the Laurentide ice sheet. J. Climate 20, 5126-5133.

Chevalier, M.-L., Ryerson, F.J., Tapponnier, P., Finkel, R.C., Van der Woerd, J., Li H.B., Liu, Q., 2005. Slip-rate measurements on the Karakorum Fault may imply secular variations in Fault motion. Science 307, 411-414.

Chevalier, M.-L., Hilley, G., Tapponnier, P., Van der Woerd, J., Jing, L.Z., Finkel, R.C., Ryerson, F.J., Li, H.B., Liu, X.H., in press. Constraints on the late Quaternary glaciations in Tibet from cosmogenic exposure ages of moraine surfaces. Quat. Sci. Rev.

Chmeleff, J., von Blanckenburg, F., Kossert, K., Jakob, D., 2010. Determination of the ${ }^{10} \mathrm{Be}$ half-life by multicollector ICP-MS and liquid scintillation counting. Nucl. Instrum. Methods. Phys. Res. B 268, 192-199.

Clark, D.H., Bierman, P.R., Larsen, P., 1995. Improving in situ cosmogenic chronometers. Quat. Res. 44, 367-377.

Clark, J., McCabe, A.M., Schnabel, C., Clark, P.U., Freeman, S., Maden, C., Xu, S., 2009a. ${ }^{10} \mathrm{Be}$ chronology of the last deglaciation of County Donegal, northwestern Ireland. Boreas 38, 111-118.
Clark, J., McCabe, A.M., Schnabel, C., Clark, P.U., McCarron, S., Freeman, S.P.H.T., Maden, C., Xu, S., 2009b. Cosmogenic ${ }^{10}$ Be chronology of the last deglaciation of western Ireland, and implications for sensitivity of the Irish ice sheet to climate change. Geol. Soc. Am. Bull. 121, 3-16.

Clark. P.U., Brook, E.J., Raisbeck, G.M., Yiou, F., Clark, J., 2003. Cosmogenic ${ }^{10}$ Be ages of the Saglek moraines, Torngat Mountains, Labrador. Geology 31, 617-620.

Colgan, P.M., Munroe, J.S., Zhou, S.Z., 2006. Cosmogenic radionuclide evidence for the limited extent of last glacial maximum glaciers in the Tanggula Shan of the central Tibetan Plateau. Quat. Res. 65, 336-339.

Davis, P.T., Bierman, P.R., Marsella, K.A., Caffee, M.W., Southon, J.R., 1999. Cosmogenic analysis of glacial terrains in the eastern Canadian Arctic: a test for inherited nuclides and the effectiveness of glacial erosion. Ann. Glaciol. 28, 181-188.

Davis, P.T., Briner, J.P., Coulthard, R.D., Finkel, R.W., Miller, G.H., 2006. Preservation of Arctic landscapes overridden by cold-based ice sheets. Quat. Res. 65, 156-163.

Derbyshire, E., Shi, Y.F., Li, J.J., Zheng, B.X., Li, S.J., Wang, J.T., 1991. Quaternary glaciation of Tibet: the geological evidence. Quat. Sci. Rev. 10, 485-510.

Dortch, J.M., Owen, L.A., Caffee, M.W., 2010a. Quaternary glaciation in the Nubra and Shyok valley confluence, northernmost Ladakh, India. Quat. Res. 74, 132-144.

Dortch, J.M., Owen, L.A., Caffee, M.W., Brease, P., 2010b. Late Quaternary glaciation and equilibrium line altitude variations of the McKinley River region, central Alaska Range. Boreas 39, 233-246.

Dyke, A.S., Moore, A., Robinson, L., 2003. Deglaciation of North America. Geol. Surv. Canada Open File 1574.

Ehlers, J., Gibbard, P.L., 2007. The extent and chronology of Cenozoic Global Glaciation. Quat. Int. 164-165, 6-20.

Everest, J., Kubik, P., 2006. The deglaciation of eastern Scotland: cosmogenic ${ }^{10} \mathrm{Be}$ evidence for a lateglacial stillstand. J. Quat. Sci. 21, 95-104.

Everest, J.D., Bradwell, T., Fogwill, C.J., Kubik, P.W., 2006. Cosmogenic ${ }^{10}$ Be age constraints for the western Ross readvance moraine: insights into British ice-sheet behaviour. Geograf. Ann. 88A, 9-17.

Fabel, D., Harbor, J., 1999. The use of in-situ produced cosmogenic radionuclides in glaciology and glacial geomorphology. Ann. Glaciol. 28, 103-110.

Fabel, D., Stroeven, A.P., Harbor, J., Kleman, J., Elmore, D., Fink, D., 2002. Landscape preservation under Fennoscandian ice sheets determined from in situ produced ${ }^{10} \mathrm{Be}$ and ${ }^{26}$ Al. Earth Planet. Sci. Lett. 201, 397-406.

Fabel, D., Fink, D., Fredin, O., Harbor, J., Land, M., Stroeven, A.P., 2006. Exposure ages from relict lateral moraines overridden by the Fennoscandian ice sheet. Quat. Res. 65, 136-146.

Finkel, R.C., Owen, L.A., Barnard, P.L., Caffee, M.W., 2003. Beryllium-10 dating of Mount Everest moraines indicates a strong monsoon influence and glacial synchroneity throughout the Himalaya. Geology 31, 561-564.

Fjellanger, J., Sorbel, L., Linge, H., Brook, E.J., Raisbeck, G.M., Yiou, F., 2006. Glacial survival of blockfields on the Varanger Peninsula, northern Norway. Geomorphology $82,255-272$

Gayer, E., Lavé, J., Pik, R., France-Lanord, C., 2006. Monsoonal forcing of Holocene glacier fluctuations in Ganesh Himal (central Nepal) constrained by cosmogenic $3 \mathrm{He}$ exposure ages of garnets. Earth Planet. Sci. Lett. 252, 275-288.

Goehring, B.M., Brook, E.J., Linge, H., Raisbeck, G.M., Yiou, F., 2008. Beryllium-10 exposure ages of erratic boulders in southern Norway and implications for the history of the Fennoscandian ice sheet. Quat. Sci. Rev. 27, 320-336.

Golledge, N. R., Fabel, D., Everest, J. D., Freeman, S. \& Binnie, S., 2007. First cosmogenic ${ }^{10} \mathrm{Be}$ age constraint on the timing of Younger Dryas glaciation and ice cap thickness, western Scottish highlands. J. Quat. Sci. 22, 785-791.

Goodfellow, B.W., 2007. Relict non-glacial surfaces in formerly glaciated landscapes. Earth-Sci. Rev. 80, 47-73.

Gosse, J.C., Phillips, F.M., 2001. Terrestrial in situ cosmogenic nuclides: theory and application. Quat. Sci. Rev. 20, 1475-1560.

Gosse, J.C., Bell, T., Gray, J.T., Klein, J., Yang, G., Finkel, R., 2006. Using cosmogenic isotopes to interpret the landscape record of glaciation: nunataks in Newfoundland?, in: Knight, P.G. (Ed.), Glacier Science And Environmental Change. Blackwell Publishing, Oxford, pp. 442-446.

Graf, A.A., Strasky, S., Zhao, Z.Z., Akçar, N., Ivy-Ochs, S., Kubik, P.W., Christl, M., Kasper, H.U., Wieler, R., Schlüchter, C., 2008. Glacier extension on the eastern Tibetan Plateau in response to MIS 2 cooling, with a contribution to ${ }^{10} \mathrm{Be}$ and ${ }^{21} \mathrm{Ne}$ methodology, in: Strasky, S., Glacial response to global climate changes: cosmogenic nuclide chronologies from high and low latitudes. PhD Thesis, ETH Zürich.

Granger, D.E., Smith, A.L., 2000. Dating buried sediments using radioactive decay and muogenic production of ${ }^{26} \mathrm{Al}$ and ${ }^{10} \mathrm{Be}$. Nucl. Instrum. Methods. Phys. Res. B 172, 822826.

Gyllencreutz, R., Mangerud, J., Svendsen, J.-I., Lohne, Ø., 2007a. A new reconstruction and database of build-up and deglaciation of the Eurasian ice sheet. Bjerknes Days Poster, Bjerknes Centre for Climate Research, Bergen. 
Gyllencreutz, R., Mangerud, J., Svendsen, J.-I., Lohne, Ø., 2007b. DATED - a GIS-based reconstruction and dating database of the Eurasian deglaciation. Geol. Surv. Finland Spec. Paper 46, 113-120.

Hallet, B., Putkonen, J., 1994. Surface dating of dynamic landforms: young boulders on aging moraines. Science 265, 937-940

Harbor, J., Stroeven, A.P., Fabel, D., Clarhäll, A., Kleman, J., Li, Y.K., Elmore, D., Fink, D., 2006. Cosmogenic nuclide evidence for minimal erosion across two subglacial sliding boundaries of the late glacial Fennoscandian ice sheet. Geomorphology 75, 90-99.

Hedrick, K.A., Seong, Y.B., Owen, L.A., Caffee, M.W., Dietsch, C., in press. Towards defining the transition in style and timing of Quaternary glaciation between the monsoon-influenced Greater Himalaya and the semi-arid Transhimalaya of Northern India. Quat. Int.

Heimsath, A.M., McGlynn, R., 2008. Quantifying periglacial erosion in the Nepal high Himalaya. Geomorphology 97, 5-23.

Hein, A.S., Hulton, N.R.J., Dunai, T.J., Schnabel, C., Kaplan, M.R., Naylor, M., Xu, S., 2009. Middle Pleistocene glaciation in Patagonia dated by cosmogenic-nuclide measurements on outwash gravels. Earth Planet. Sci. Lett. 286, 184-197.

Heine, K., Reuther, A.U., Thieke, H.U., Schulz, R., Schlaak, N., Kubik, P.W., 2009. Timing of Weichselian ice marginal positions in Brandenburg (northeastern Germany) using cosmogenic in situ ${ }^{10}$ Be. Zeitschr. Geomorph. 53, 433-454.

Heyman, J., Stroeven, A.P., Caffee, M.W., Hättestrand, C., Harbor, J., Li, Y.K., Alexanderson, H., Zhou, L.P., Hubbard, A., 2010. Palaeoglaciology of Bayan Har Shan, NE Tibetan Plateau: the case of a missing LGM expansion, In: Heyman, J., Palaeoglaciology of the northeastern Tibetan Plateau. PhD thesis, Stockholm University.

Johnsen, T.F., Alexanderson, H., Fabel, D., Freeman, S.P.H.T., 2009. New ${ }^{10}$ Be cosmogenic ages from the Vimmerby moraine confirm the timing of Scandinavian ice sheet deglaciation in southern Sweden. Geograf. Ann. 91A, 113-120.

Johnsen, T.F., Fabel, D., Stroeven, A.P., 2010. High-elevation cosmogenic nuclide dating of the last deglaciation in the central Swedish mountains: implications for the timing of tree establishment, In: Johnsen, T.F., Late Quaternary ice sheet history and dynamics in central and southern Scandinavia. $\mathrm{PhD}$ thesis, Stockholm University.

Kaplan, M.R., Miller, G.H., Steig, E.J., 2001. Low-gradient outlet glaciers (ice streams?) drained the Laurentide ice sheet. Geology 29, 343-346.

Kelly, M.A., Lowell, T.V., Hall, B.L., Schaefer, J.M., Finkel, R.C., Goehring, B.M., Alley, R.B., Denton, G.H., 2008. A ${ }^{10}$ Be chronology of lateglacial and Holocene mountain glaciation in the Scoresby Sund region, east Greenland: implications for seasonality during lateglacial time. Quat. Sci. Rev. 27, 2273-2282.

Kleman, J., Hättestrand C., 1999. Frozen-bed Fennoscandian and Laurentide ice sheets during the Last Glacial Maximum. Nature 402, 63-66.

Kleman, J., Stroeven, A.P., 1997. Preglacial surface remnants and Quatemary glacial regimes in northwestern Sweden. Geomorphology 19, 35-54.

Kleman, J., Stroeven, A.P., Lundqvist, J., 2008. Patterns of Quaternary ice sheet erosion and deposition in Fennoscandia and a theoretical framework for explanation. Geomorphology 97, 73-90.

Kleman, J., Jansson, K.N., De Angelis, H., Stroeven, A.P., Hättestrand, C., Alm, G., Glasser, N.F., 2010. North American Ice Sheet build-up during the last glacial cycle, 115-21 kyr. Quat. Sci. Rev. 29, 2036-2051.

Kong, P., Na, C.G., Fink, D., Ding, L., Huang, F.X., 2007. Erosion in northwest Tibet from in-situ-produced cosmogenic ${ }^{10} \mathrm{Be}$ and ${ }^{26} \mathrm{Al}$ in bedrock. Earth Surf. Proc. Land. 32, 116125.

Kong, P., Fink, D., Na, C.G., Huang, F.X., 2009a. Late Quaternary glaciation of the Tianshan, central Asia, using cosmogenic ${ }^{10} \mathrm{Be}$ surface exposure dating. Quat. Res. 72, 229-233.

Kong, P., Na, C.G., Fink, D., Zhao, X.T., Xiao, W., 2009b. Moraine dam related to late Quaternary glaciation in the Yulong Mountains, southwest China, and impacts on the Jinsha River. Quat. Sci. Rev. 28, 3224-3235.

Koppes, M., Gillespie, A.R., Burke, R.M., Thompson, S.C., Stone, J., 2008. Late Quaternary glaciation in the Kyrgyz Tien Shan. Quat. Sci. Rev. 27, 846-866.

Korschinek, G., Bergmaier, A., Faestermann, T, Gerstmann, U.C., Knie, K., Rugel, G., Wallner, A., Dillmann, I., Dollinger, G., von Gostomski, C.L., Kossert, K., Maiti, M., Poutivtsev, M., Remmert, A., 2010. A new value for the half-life of ${ }^{10} \mathrm{Be}$ by heavy-ion elastic recoil detection and liquid scintillation counting. Nucl. Instrum. Methods. Phys. Res. B 268, 187-191.

Lal, D., 1991. Cosmic ray labeling of erosion surfaces: in situ nuclide production rates and erosion models. Earth Planet. Sci. Lett. 104, 424-439.

Lal, D., Harris, N.B.W., Sharma, K.K., Gu, Z.Y., Ding, L., Liu, T.S., Dong, W.Q., Caffee, M.W., Jull, A.J.T., 2003. Erosion history of the Tibetan Plateau since the last interglacial: constraints from the first studies of cosmogenic ${ }^{10} \mathrm{Be}$ from Tibetan bedrock. Earth Planet. Sci. Lett. 217, 33-42.
Lasserre, C., Gaudemer, Y., Tapponnier, P., Mériaux, A.-S., Van der Woerd, J., Yuan, D.Y. Ryerson, F.J., Finkel, R.C., Caffee, M.W., 2002. Fast late Pleistocene slip rate on the Leng Long Ling segment of the Haiyuan fault, Qinghai, China. J. Geophys. Res. 107, B11 2276.

Lehmkuhl, F., Owen, L.A., 2005. Late Quaternary glaciation of Tibet and the bordering mountains: a review. Boreas 34, 87-100.

Linge, H., Larsen, E., Kjær, K.H., Demidov, I.N., Brook, E.J., Raisbeck, G.M., Yiou, F., 2006. Cosmogenic ${ }^{10} \mathrm{Be}$ exposure age dating across Early to Late Weichselian icemarginal zones in northwestern Russia. Boreas 35, 576-586.

Licciardi, J.M., Schaefer, J.M., Taggart, J.R., Lund, D.C., 2009. Holocene glacier fluctuations in the Peruvian Andes indicate northern climate linkages. Science 325, 1677-1679.

Lukas, S., Bradwell, T., 2010. Reconstruction of a lateglacial (Younger Dryas) mountain ice field in Sutherland, northwestern Scotland, and its palaeoclimatic implications. J. Quat. Sci. 25, 567-580.

Marquette, G.C., Gray, J.T., Gosse, J.C., Courchesne, F., Stockli, L., Macpherson, G., Finkel, R., 2004. Felsenmeer persistence under non-erosive ice in the Torngat and Kaumajet Mountains, Quebec and Labrador, as determined by soil weathering and cosmogenic nuclide exposure dating. Can. J. Earth Sci. 41, 19-38.

Marsella, K.A., 1998. Timing and extent of glaciation in the Pangnirtung Fjord region, Baffin Island: determined using in situ produced cosmogenic ${ }^{10} \mathrm{Be}$ and ${ }^{26} \mathrm{Al}$. Ms thesis, University of Vermont.

Marsella, K.A., Bierman, P.R., Davis, P.T., Caffee, M.W., 2000. Cosmogenic ${ }^{10} \mathrm{Be}$ and ${ }^{26} \mathrm{Al}$ ages for the last glacial maximum, eastern Baffin Island, arctic Canada. Geol. Soc. Am. Bull. 112, 1296-1312.

Matthews, J.A., Shakesby, R.A., Schnabel, C., Freeman, S., 2008. Cosmogenic ${ }^{10} \mathrm{Be}$ and ${ }^{26} \mathrm{Al}$ ages of Holocene moraines in southern Norway I: testing the method and confirmation of the date of the Erdalen event (c. $10 \mathrm{ka}$ ) at its type-site. The Holocene 18, 1155-1164.

McCarroll, D., Stone, J.O., Ballantyne, C.K., Scourse, J.D., Fifield, L.K., Evans, D.J.A., Hiemstra, J.F.,2010. Exposure-age constraints on the extent, timing and rate of retreat of the last Irish Sea ice stream. Quat. Sci. Rev. 29, 1844-1852.

Mériaux, A.-S., Ryerson, F.J., Tapponnier, P., Van der Woerd, J., Finkel, R.C., Xu, X.W., Xu, Z.Q., Caffee, M.W., 2004. Rapid slip along the central Altyn Tagh Fault: Morphochronologic evidence from Cherchen He and Sulamu Tagh. J. Geophys. Res. 109, B06401.

Nesje, A., Dahl, S.O., Linge, H., Ballantyne, C.K., McCarroll, D., Brook, E.J., Raisbeck, G.M., Yiou, F., 2007. The surface geometry of the last glacial maximum ice sheet in the Andøya-Skånland region, northern Norway, constrained by surface exposure dating and clay mineralogy. Boreas 36, 227-239.

Nishiizumi, K., Winterer, E., Kohl, C., Klein, J., Middleton, R., Lal, D., Arnold, J., 1989. Cosmic ray production rates of ${ }^{26} \mathrm{Al}$ and ${ }^{10} \mathrm{Be}$ in quartz from glacially polished rocks. $\mathrm{J}$. Geophys. Res. 94, 17907-17915.

Nishiizumi, K., Imamura, M., Caffee, M.W., Southon, J.R., Finkel, R.C., McAninch, J., 2007. Absolute calibration of ${ }^{10} \mathrm{Be}$ AMS standards. Nucl. Instrum. Methods. Phys. Res. B 258, 403-413.

Owen, L.A., Gualtieri, L., Finkel, R.C., Caffee, M.W., Benn, D.I., Sharma, M.C., 2001. Cosmogenic radionuclide dating of glacial landforms in the Lahul Himalaya, northern India: defining the timing of late Quaternary glaciations. J. Quat. Sci. 16, 555-563.

Owen, L.A., Finkel, R.C., Caffee, M.W., Gualtieri, L., 2002. Timing of multiple late Quaternary glaciations in the Hunza Valley, Karakoram Mountains, northern Pakistan: defined by cosmogenic radionuclide dating of moraines. Geol. Soc. Am. Bull. 114, 593604.

Owen, L.A., Finkel, R.C., Haizhou, M., Spencer, J.Q., Derbyshire, E., Barnard, P.L., Caffee, M.W., 2003a. Timing and style of Late Quaternary glaciation in northeastern Tibet Geol. Soc. Am. Bull. 115, 1356-1364.

Owen, L.A., Ma, H.Z., Derbyshire, E., Spencer, J.Q., Barnard, P.L., Nian, Z.Y., Finkel, R.C., Caffee, M.W., 2003b. The timing and style of late Quaternary glaciation in the La Ji Mountains, NE Tibet: evidence for restricted glaciation during the latter part of the last glacial. Zeitschr. Geomorph. Suppl. 130, 263-276.

Owen, L.A., Spencer, J.Q., Ma, H.Z., Barnard, P.L., Derbyshire, E., Finkel, R.C., Caffee, M.W., Nian, Z.Y., 2003c. Timing of Late Quaternary glaciation along the southwestern slopes of the Qilian Shan, Tibet. Boreas 32, 281-291.

Owen, L.A., Finkel, R.C., Barnard, P.L., Ma, H.Z., Asahi, K., Caffee, M.W., Derbyshire, E., 2005. Climatic and topographic controls on the style and timing of late Quaternary glaciation throughout Tibet and the Himalaya defined by ${ }^{10} \mathrm{Be}$ cosmogenic radionuclide surface exposure dating. Quat. Sci. Rev. 24, 1391-1411.

Owen, L.A., Caffee, M.W., Bovard, K.R., Finkel, R.C., Sharma, M.C., 2006a. Terrestrial cosmogenic nuclide surface exposure dating of the oldest glacial successions in the Himalayan orogen: Ladakh Range, northern India. Geol. Soc. Am. Bull. 118, 383-392. 
Owen, L.A., Finkel, R.C., Ma, H.Z., Barnard, P.L., 2006b. Late Quaternary landscape evolution in the Kunlun Mountains and Qaidam basin, northern Tibet: a framework for examining the links between glaciation, lake level changes and alluvial fan formation. Quat. Int. 154-155, 73-86.

Owen, L.A., Caffee, M.W., Finkel, R.C., Seong, Y.B., 2008. Quaternary glaciation of the Himalayan-Tibetan orogen. J. Quat. Sci. 23, 513-531.

Owen, L.A., Robinson, R., Benn, D.I., Finkel, R.C., Davis, N.K., Yi, C.L., Putkonen, J., Li, D.W., Murray, A.S., 2009. Quaternary glaciation of Mount Everest. Quat. Sci. Rev. 28, 1412-1433.

Owen, L.A., Yi, C.L., Finkel, R.C., Davis, N.K., 2010. Quaternary glaciation of Gurla Mandhata (Naimon'anyi). Quat. Sci. Rev. 29, 1817-1830.

Phillips, W.M., Sloan, V.F., Shroder, J.F., Sharma, P., Clarke, M.L., Rendell, H.M., 2000. Asynchronous glaciation at Nanga Parbat, northwestern Himalaya mountains, Pakistan. Geology 28, 431-434.

Phillips, W.M., Hall, A.M., Mottram, R., Fifield, L.K., Sugden, D.E., 2006. Cosmogenic ${ }^{10} \mathrm{Be}$ and ${ }^{26} \mathrm{Al}$ exposure ages of tors and erratics, Cairngorm Mountains, Scotland: timescales for the development of a classic landscape of selective linear glacial erosion. Geomorphology 73, 222-245.

Phillips, W.M., Hall, A.M., Ballantyne, C.K., Binnie, S., Kubik, P.W., Freeman, S., 2008. Extent of the last ice sheet in northern Scotland tested with cosmogenic ${ }^{10} \mathrm{Be}$ exposure ages. J. Quat. Sci. 23, 101-107.

Porter, S.C., 1989. Some geological implications of average Quaternary glacial conditions. Quat. Res. 32, 245-261.

Pratt-Sitaula, B., 2005. Glaciers, climate, and topography in the Nepalese Himalaya. PhD Thesis, University of California, Santa Barbara.

Putkonen, J., O'Neal, M., 2006. Degradation of unconsolidated Quaternary landforms in the western North America. Geomorphology 75, 408-419.

Putkonen, J., Swanson, T., 2003. Accuracy of cosmogenic ages for moraines. Quat. Res. $59,255-260$.

Rinterknecht, V.R., Clark, P.U., Raisbeck, G.M., Yiou, F., Brook, E.J., Tschudi, S., Lunkka, J.P., 2004. Cosmogenic ${ }^{10} \mathrm{Be}$ dating of the Salpausselkä I moraine in southwestern Finland. Quat. Sci. Rev. 23, 2283-2289.

Rinterknecht, V.R., Marks, L., Piotrowski, J.A., Raisbeck, G.M., Yiou, F., Brook, E.J., Clark, P.U., 2005. Cosmogenic ${ }^{10} \mathrm{Be}$ ages on the Pomeranian moraine, Poland. Boreas 34, 186-191.

Rinterknecht, V.R., Clark, P.U., Raisbeck, G.M., Yiou, F., Bitinas, A., Brook, E.J., Marks, L., Zelčs, V., Lunkka, J.-P., Pavlovskaya, I.E., Piotrowski, J.A., Raukas, A., 2006. The last deglaciation of the southeastern sector of the Scandinavian ice sheet. Science 311, 1449-1452.

Rinterknecht, V., Braucher, R., Böse, M., Bourlès, D., Mercier, J.-L., in press. Late Quaternary ice sheet extents in northeastern Germany inferred from surface exposure dating. Quat. Sci. Rev.

Schaefer, J.M., Oberholzer, P., Zhao, Z.Z., Ivy-Ochs, S.4, Wieler, R., Baur, H., Kubik, P.W., Schlüchter, C., 2008. Cosmogenic beryllium-10 and neon-21 dating of late Pleistocene glaciations in Nyalam, monsoonal Himalayas. Quat. Sci. Rev. 27, 295-311.

Schaefer, J.M., Denton, G.H., Kaplan, M., Putnam, A., Finkel, R.C., Barrell, D.J.A., Andersen, B.G., Schwartz, R., Mackintosh, A., Chinn, T., Schlüchter, C., 2009. Highfrequency Holocene glacier fluctuations in New Zealand differ from the northern signature. Science 324, 622-625.

Schäfer, J.M., 2000. Reconstruction of landscape evolution and continental paleoglaciations using in-situ cosmogenic nuclides: examples from Antarctica and the Tibetan Plateau. PhD Thesis, ETH Zürich.

Schäfer, J.M., Tschudi, S., Zhao, Z.Z., Wu, X.H., Ivy-Ochs, S., Wieler, R., Baur,H., Kubik, P.W., Schlüchter, C., 2002. The limited infuence of glaciations in Tibet on global climate over the past 170000 yr. Earth Planet. Sci. Lett. 194, 287-297.
Scherler, D., Bookhagen, B., Strecker, M.R., von Blanckenburg, F., Rood, D., 2010. Timing and extent of late Quaternary glaciation in the western Himalaya constrained by ${ }^{10} \mathrm{Be}$ moraine dating in Garhwal, India. Quat. Sci. Rev. 29, 815-831.

Seong, Y.B., Owen, L.A., Bishop, M.P., Bush, A., Clendon, P., Copland, L., Finkel, R., Kamp, U., Shroder, J.F., 2007. Quaternary glacial history of the central Karakoram. Quat. Sci. Rev. 26, 3384-3405.

Seong, Y.B., Owen, L.A., Yi, C.L., Finkel, R.C., 2009. Quaternary glaciation of Muztag Ata and Kongur Shan: evidence for glacier response to rapid climate changes throughout the late glacial and Holocene in westernmost Tibet. Geol. Soc. Am. Bull. 121, 348-365.

Shakesby, R.A., Matthews, J.A., Schnabel, C., 2008. Cosmogenic ${ }^{10} \mathrm{Be}$ and ${ }^{26} \mathrm{Al}$ ages of Holocene moraines in southern Norway II: evidence for individualistic responses of high-altitude glaciers to millennial-scale climatic fluctuations. The Holocene 18, 11651177.

Smith, C.A., Lowell, T.V., Owen, L.A., Caffee, M.W., in press. Late Quaternary glacial chronology on Nevado Illimani, Bolivia, and the implications for paleoclimatic reconstructions across the Andes. Quat. Res.

Staiger, J.K.W., Gosse, J.C., Johnson, J.V., Fastook, J., Gray, J.T., Stockli, D.F., Stockli, L., Finkel, R., 2005. Quaternary relief generation by polythermal glacier ice. Earth Surf. Proc. Land. 30, 1145-1159.

Stone, J.O., 2000. Air pressure and cosmogenic isotope production. J. Geophys. Res. 105 (B10), 23753-23759.

Stone, J.O., Ballantyne, C.K., Fifield, L.K., 1998. Exposure dating and validation of periglacial weathering limits, northwest Scotland. Geology 26, 587-590.

Strasky, S., Graf, A.A., Zhao, Z.Z., Kubik, P.W., Baur, H., Schlüchter, C., Wieler, R., 2009. Late glacial ice advances in southeast Tibet. J. Asian Earth Sci. 34, 458-465.

Stroeven, A.P., Fabel, D., Hättestrand, C., Harbor, J., 2002. A relict landscape in the centre of Fennoscandian glaciation: cosmogenic radionuclide evidence of tors preserved through multiple glacial cycles. Geomorphology 44, 145-154.

Tschudi, S., Ivy-Ochs, S., Schlüchter, C., Kubik, P., Rainio, H., 2000. ${ }^{10}$ Be dating of Younger Dryas Salpausselkä I formation in Finland. Boreas 29, 287-293.

Tschudi, S., Schäfer, J.M., Zhao, Z.Z., Wu, X.H., Ivy-Ochs, S., Kubik, P.W., Schlüchter, C., 2003. Glacial advances in Tibet during the Younger Dryas? Evidence from cosmogenic ${ }^{10} \mathrm{Be},{ }^{26} \mathrm{Al}$, and ${ }^{21} \mathrm{Ne}$. J. Asian Earth Sci. 22, 301-306.

Wang, J., Yiou, F., Raisbeck, G., Xu, X.B., 2003. Reconstructing the history of drift boulders' movement by using the autochthonous cosmogenic isotope ${ }^{10} \mathrm{Be}$. Acta Geol. Sinica 77, 407-413. [In Chinese, English abstract].

Wang, J., Raisbeck, G., Xu, X.B., Yiou, F., Bai, S.B., 2006. In situ cosmogenic ${ }^{10}$ Be dating of the Quaternary glaciations in the southern Shaluli Mountain on the southeastern Tibetan Plateau. Sci. China Series D: Earth Sci. 49, 1291-1298.

Winkler, S., 2009. First attempt to combine terrestrial cosmogenic nuclide $\left({ }^{10} \mathrm{Be}\right)$ and Schmidt hammer relative-age dating: Strauchon Glacier, Southern Alps, New Zealand. Centr. Eur. J. Geosci. 1, 274-290.

Zech, R., Abramowski, U., Glaser, B., Sosin, P., Kubik, P.W., Zech, W., 2005a. Late Quaternary glacial and climate history of the Pamir Mountains derived from cosmogenic ${ }^{10}$ Be exposure ages. Quat. Res. 64, 212-220.

Zech, R., Glaser, B., Sosin, P., Kubik, P.W., Zech, W., 2005b. Evidence for long-lasting landform surface instability on hummocky moraines in the Pamir Mountains (Tajikistan) from ${ }^{10} \mathrm{Be}$ surface exposure dating. Earth Planet. Sci. Lett. 237, 453-461.

Zech, R., Zech, M., Kubik, P.W., Kharki, K., Zech, W., 2009. Deglaciation and landscape history around Annapurna, Nepal, based on ${ }^{10} \mathrm{Be}$ surface exposure dating. Quat. Sci. Rev. 28, 1106-1118.

Zhou, S.Z., Xu, L.B., Colgan, P.M., Mickelson, D.M., Wang, X.L., Wang, J., Zhong, W., 2007. Cosmogenic ${ }^{10} \mathrm{Be}$ dating of Guxiang and Baiyu glaciations. Chinese Sci. Bull. $52,1387-1393$. 